\title{
Invisible Enemies: Coronavirus and Other Hidden Threats
}

\author{
D. M. Shaw 1
}

Received: 5 May 2020 / Accepted: 3 August 2020

(C) Journal of Bioethical Inquiry Pty Ltd. 2020

\begin{abstract}
To say that coronavirus is highly visible is a massive understatement in terms of its omnipresence in our lives and media coverage concerning it, yet also clearly untrue in terms of the virus itself. COVID-19 is our invisible enemy, changing our lives radically without ever revealing itself directly. In this paper I explore its invisibility and how it relates to and exposes other invisible enemies we are and have been fighting, in many cases without even realizing. First, I analyse the virus itself and how its stealthy nature has transformed our lives. Second, I describe how the invisible epidemic of social media sharing of fake news about the virus worsens the situation further. Third, I explore how the virus has revealed to us what really matters in our lives and has forced us to re-evaluate our priorities. Fourth, I go on to explore the underlying structural weaknesses and disparities in society that have been exposed by the virus but previously remained unconsidered for so long that they too have become camouflaged, even if their effects are all too apparent; like the virus, neoliberal capitalism is an invisible enemy that has made prisoners of us all. I conclude by suggesting that the coronavirus pandemic represents a hidden opportunity to overcome perhaps the biggest invisible enemy of all: the moral distance that separates us from others. Only by
\end{abstract}

D. M. Shaw $(\bowtie)$

Institute for Biomedical Ethics, University of Basel, Basel,

Switzerland

e-mail: David.shaw@unibas.ch

D. M. Shaw

Care and Public Health Research Institute, Maastricht University, Maastricht, The Netherlands rendering the rest of humanity morally visible to ourselves can we overcome capitalism and stop treating other people as invisible enemies.

Keywords Coronavirus · Ethics · Social distancing · Capitalism $\cdot$ Inequalities $\cdot$ Public health

\section{The Invisible Enemy}

The coronavirus is invisible, but its effects are visible everywhere. Most people in the United Kingdom have been confined to their homes, venturing out only for shopping and occasional exercise. When we do go out for a walk, we cross the street to avoid walking within two metres of anyone not in our households. Playparks and schools are closed; streets are quiet; flights have almost stopped. And those are just the effects on our everyday lives; the most terrible effect is the increase in the number of deaths attributable to the virus. Non-essential operations and treatments have been stopped, intensive care units are overwhelmed, and even there, 50 per cent of COVID-19 patients who get a bed will not make it out alive. All of this because an invisible virus jumped from a bat to a pangolin to a human and then on to millions more people.

Of course, if we could actually see the virus, it would be much easier to deal with it. If, as my son Sam has suggested, the virus was basically just little red guys who jump between people making them sick, we could easily see who to cross the road to avoid and who not. But the insidious nature of the virus means that this is not so; 
virus particles are microscopic and invisible. This means that we do not know who we need to avoid and who we do not need to avoid, leading to physical distancing from everyone who is not in our household. And although we now call it physical rather than social distancing (a phrase with an interesting history-see Scherlis 2020) and though it is clearly necessary for our and for public health, it still seems antisocial to cross the road to avoid people, whether they are strangers or neighbours. This is the nature of the invisible enemy; it forces us to treat everyone we see as an enemy because they might be unwittingly harbouring the enemy. And of course, the virus remains entirely imperceptible even to many people who are actually infected with it. This makes dealing with lockdown restrictions even harder; it is easier to comply if you know you are sick, as you will (rightly or wrongly) believe that you have the virus, making it more likely that you will be happy to stay at home to protect others. And finally, of course, the invisible nature of the virus means that it is difficult to tell when we have defeated it. Only mass antibody testing will reveal who has and has not encountered the invisible enemy.

\section{The Invisible Infection of Misinformation}

Another invisible enemy is propagating unseen behind the scenes through social media: misinformation and fake news about the virus. Concise and effective communication of information about the virus is essential to combating its spread and protecting the public, and daily governmental briefings in most countries have aimed to ensure that accurate facts are provided. However, social media makes it very easy for rumour and misinformation to spread. Just as it is very easy to pass the coronavirus to someone else, so it is easy to pass on fake news using WhatsApp or other social media apps. It is no coincidence that rapid sharing of articles on social media results in a phenomenon that borrows the language of virology; when such stories "go viral," there can be serious detrimental effects.

Two prominent examples occurred in March 2020. First, a message purporting to be from St George's Hospital circulated widely (Topping 2020). It claimed that drinking "abundant hot water" kills the virus and recommended a test for it: "Breathe in deeply and hold your breath for 10 seconds. If this can be done without coughing ... this shows that there is no fibrosis in the lungs, indicating the absence of infection." This is total nonsense, but as some of the message seemed sensible, it will have fooled many people. This is extremely dangerous; people who believe this misinformation and who have the virus might well believe they do not have it because they can pass this test. Potentially even more serious is the entirely fake claim that 5G mobile phone masts are related to the spread of the virus. As well as playing on pre-existing concerns about the potential health risks of $5 \mathrm{G}$ technology, this misinformation poses a genuine public health threat because people who believe it have actually set fire to dozens of such masts across England (Sweney and Waterson 2020). There is no evidence whatsoever for this claim, yet it has led to dangerous vandalism by people who should know better.

In response to concerns about the spread of fake news during the coronavirus crisis, WhatsApp first limited the number of groups to which a message could be forwarded to five; a few weeks later this was changed to one. While users can still manually repeat the process to forward to a limitless number, this may be a helpful nudge in the right direction. Nonetheless, what is really needed to combat this particular invisible enemy is a sense of responsibility and the ability to use critical thinking before sharing any information about the virus. By forwarding false information, members of the public collude with this insidious invisible enemy; taking a minute to think about and check the truth of such claims before sharing them with friendswho are likely to trust the information because a friend forwarded it—is essential (Shaw 2020a).

\section{Other Invisible Viruses}

The important process of suspecting, identifying, and rejecting fake news mirrors the re-evaluation of our lives that the virus has forced upon many of us. The closure of schools and nurseries and the mass advent of working and schooling from home means that parents and children are getting much more time together than they would in normal times, enabling families to spend quality time together, which for many families might have been in short supply. Other things that we had taken for granted, such as freedom of movement, going to the pub, and seeing and hugging relatives and friends, suddenly seem much more precious; absence makes the heart grow fonder. This extra time at home can have its downsides, however: it increases the risk of anxiety and depression; there may be difficult relationships within the home, including abuse or neglect; and many children will be deprived of their school meals (Shaw 2020b). 
While this new set-up may be harmful or a major inconvenience for many people, for some it forces or facilitates a re-assessment of the normal model; perhaps it is not that the virus has forced us to live in a way that seems wrong but that our old lives were fake, just like much WhatsApp 'news'. Why do we spend hours commuting every day to work when that means we see so little of our families? Why do we need to go into the office if (as has turned out to be true for very many) we can work from home? Did we really need to drive so much, and fly so much, and shop so much for things that don't really matter? Do we really need to earn so much? Do we really even need to earn at all? It is almost as if there is another enemy whose invisible hand is forcing us to do these things against our will.

One invisible enemy is certainly revealed by this crisis: the virus lays bare the manifold inequalities that affect modern society. Vulnerable elderly citizens living in care homes are likely to die alongside fellow residents, with clusters of COVID-19 deaths occurring and little assistance being offered to them because of a shortage of staff and personal protective equipment (Booth 2020). The elderly and some disabled people are also at more risk of being denied an intensive care bed or a ventilator because of the scarcity of these resources and the inconvenient fact that they are less likely to survive even if they get one (Shaw, Harvey, and Gardiner 2020).

But age and disability are risks for all citizens; the risk of being poor varies according to one's birth. Despite repeated claims that the virus does not discriminate, people from lower socio-economic groups are more likely to catch the virus (because they are more likely to need to keep going to work) and more likely to die of it (because of pre-existing health inequalities). Data also suggest that people from Black, Asian, and minority ethnic (BAME) backgrounds are also disproportionately more likely to die of the virus (Vazquez 2020). And those low-paid people defined (and degraded) by the government just a few months ago as being "low-skilled" (Shaw 2020c) have turned out to be the nations' lifesavers, risking their lives every day to care for patients who may well have the virus.

Other invisible inequalities are rendered solid by the virus: well-off people with nice big gardens find it much easier to cope with lockdown than people living in apartment blocks or high-rises, who have no private green space to enjoy. Very well-off people even have the luxury of getting into trouble for travelling long distances to second homes that presumably have even bigger gardens (Taylor 2020). In contrast, those living in Tower Hamlets in London lost their only large park (Tower Hamlets 2020). Lower-paid workers are less likely to have access to the internet and less likely to have jobs that enable working from home, meaning they will have to keep travelling to work, increasing the risk of getting the virus and making childcare even more difficult. Those struggling on zero-hours contracts may not receive sufficient income from the government's coronavirus benefits scheme.

Socio-economic inequalities existed for centuries before coronavirus came along, but the crisis exposes the invisible enemy that underlies all our lives. It forces us into patterns of consumption and destruction, forcing conformity to a paradigm that requires work, travel, purchasing, and development, and thereby perpetuates existing inequalities. If our fight against this new invisible enemy has one potential benefit, it is that it may force us to confront the seemingly invincible invisible enemy of neoliberal capitalism. After all, travel, development, and consumption have all virtually ceased, and work continues only along a very different paradigm that requires no commuting. The skies are clear, the roads are clear, our minds are clear, and the Earth is healing. Could our enemy's enemy be our friend?

\section{Moral Distance and Defeating Invisible Enemies}

Capitalism and coronavirus have a lot in common. Both affect entire populations and kill lots of people but spare most of us so as not to die out. Both have evolved over time, and both spare only the fittest; capitalism is economic survival of the fittest, and just like the virus, it preys on those who are worst off. And the virus owes its existence to the way that capitalism treats humans and non-human animals: the virus began in a wet market and has led to a global market crash. It would be somewhat ironic if the wholesale capitalism that instrumentalizes and kills billions of animals every year should inadvertently create a virus that actually ends up bringing down capitalism itself through its devastating effects on the invisible enemy that underlies all our lives-factory assembly lines, a key component of capitalism, have their origins in slaughterhouses in the United States in the 1870s (Shukin 2009).

But sadly, it is unlikely that coronavirus itself will be enough to finish off capitalism; it might need some help. So entrenched are our societies in the neoliberal model that 
we are likely to revert to the old way of doing things without concerted action. How can we ensure that the lessons we have quickly learned from coronavirus are not forgotten? There are already calls for governments to continue their temporarily more generous benefits schemes after the crisis has passed, but that will prove particularly difficult in the widely forecast global recession that is already showing signs of being underway. Spain has even made first steps towards a universal basic income scheme, belatedly recognizing that not everyone is able to earn at all times ( $\mathrm{Ng}$ 2020). Coronavirus has brought crisis to us all, and in so doing has finally made those in power realize that for many people crisis is the normal way of life. This can be addressed within or without the capitalistic model, but something has to change; the obvious contenders are a move to more socialist or even communist models or to some sort of universal basic income model within the confines of a more ethical capitalism.

Perhaps the key benefit that the pandemic has given us is that it has highlighted to everyone in society how others in society live, casting a harsh light on the invisible enemy of inequality and the dark network of capitalism that underlies it. The essential flaw of capitalism is that it forces us to treat other people as invisible enemies against whom we are always competing, day in, day out, in a battle to the death. Because we cannot see those people, we are morally blind to their struggle and to the harm that we are doing to them. But despite the necessity of physical distancing, coronavirus has reduced our moral distance from the people we share our planet with, revealing them to be not invisible enemies but friends in need. If we really sought to be a civilization, we would not strive to create a society that is based on an economic reincarnation of the savage ancient paradigm of survival of the fittest and instead seek to build a caring community that provides for those in need not only in times of crisis but at all times. It is sad that it took a new invisible enemy to make us see all the ones we were already fighting, but it would be sadder still if we lost sight of them again when we finally have a chance to defeat them all.

\section{References}

Booth, R. 2020. Half of coronavirus deaths happen in care homes, data from EU suggests. The Guardian, April 13. https:/www.theguardian.com/world/2020/apr/13/half-ofcoronavirus-deaths-happen-in-care-homes-data-from-eusuggests. Accessed July 26, 2020.
Ng, K. 2020. Coronavirus: Spain to become first country in Europe to roll out universal basic income. The Independent, April 6. https://www.independent.co. uk/news/world/europe/coronavirus-spain-universal-basicincome-europe-a9449336.html. Accessed July 26, 2020.

Scherlis, L. 2020. Distantiated communities: A social history of social distancing. Cabinet, April 30. http://cabinetmagazine. org/kiosk/scherlis_lily_30_april_2020.php. Accessed July 26, 2020.

Shaw, D. 2020a. Coronavirus and our duty to fight fake news: 10 simple rules. Journal of Medical Ethics Blog, April 15. https://blogs.bmj.com/medical-ethics/2020/04/15 /coronavirus-and-our-duty-to-fight-fake-news-10-simplerules/. Accessed July 26, 2020.

2020b. The vital contexts of coronavirus. Journal of Medical Ethics Blog, April 2. https://blogs.bmj. com/medical-ethics/2020/04/02/the-vital-contexts-ofcoronavirus/. Accessed July 26, 2020.

. 2020c. Who cares for the 'low-skilled' care worker? The flawed new Brexit immigration policy. Journal of Medical Ethics Blog, February 27. https://blogs.bmj.com/medicalethics/2020/02/27/who-cares-for-the-low-skilled-careworker-the-flawed-new-brexit-immigration-policy/.

Shaw, D., D. Harvey, and D. Gardiner. 2020. Don't let the ethics of despair infect the intensive care unit. Journal of Medical Ethics Blog, March 16. https://blogs.bmj.com/medicalethics/2020/03/26/dont-let-the-ethics-of-despair-infect-theintensive-care-unit/. Accessed July 26, 2020.

Shukin N. 2009. Automobility: The animal capital of cars, films and abattoirs. In Animal capital: Rendering life in biopolitical times, edited by N. Shukin, 87-130. University of Minnesota Press.

Sweney, M., and J. Waterson. 2020. Arsonists attack phone mast serving NHS Nightingale hospital. The Guardian, April 14. https://www.theguardian.com/technology/2020/apr/14 /arsonists-attack-phone-mast-serving-nhs-nightingalehospital. July 26, 2020.

Taylor, B. 2020. What on earth was Catherine Calderwood thinking? BBC News, April 6. https://www.bbc.co.uk/news/ukscotland-52186576. Accessed July 26, 2020.

Topping A. 2020. "If you have received a Whatsapp message starting like the below, the @ guardian team have factchecked the contents and found it lacking." Twitter, March 19, 2020. https://mobile.twitter. com/lexytopping/status/1240287136118648833.

Tower Hamlets Council. 2020. Update on Victoria Park, March 27. https://www.towerhamlets.gov.uk/News events/2020/March_20/Statement_on_Victoria_Park.aspx. Accessed July 26, 2020.

Vazquez, M. 2020. Surgeon general explains how coronavirus disproportionately affects people of color. CNN, April 10. https://edition.cnn.com/2020/04/10/politics/jerome-adamsminority-communities-coronavirus/index.html. Accessed July 26, 2020.

Publisher's note Springer Nature remains neutral with regard to jurisdictional claims in published maps and institutional affiliations. 